DOI: https://doi.org/10.47405/mjssh.v6i10.1110

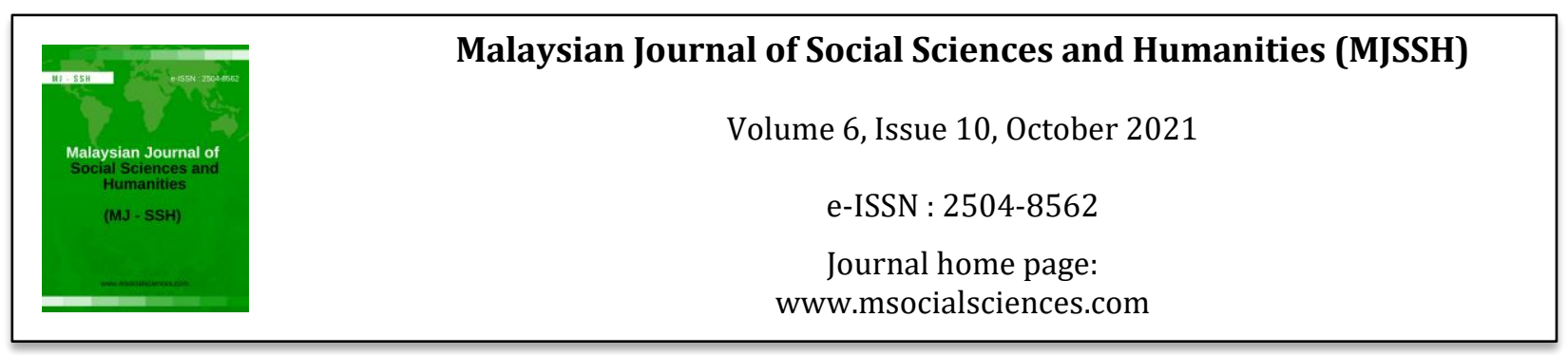

\title{
Matlamat Pendidikan untuk Pembangunan Lestari (ESD) daripada Perspektif Guru Geografi KSSM
}

\author{
Nurul Adilla Md Zain ${ }^{1}$, Kadaruddin Aiyub ${ }^{1}$ \\ ${ }^{1}$ Fakulti Sains Sosial dan Kemanusiaan, Universiti Kebangsaan Malaysia (UKM), Malaysia \\ Correspondence: Nurul Adilla Md Zain (nuruladilla07@edidik.edu.my)
}

\begin{abstract}
Abstrak
Pendidikan untuk Pembangunan Lestari (ESD) merupakan satu konsep pendidikan global yang berperanan untuk meningkatkan keupayaan dan kompetensi generasi muda sebagai warganegara global yang mampu merealisasikan Matlamat Pembangunan Lestari (SDG). Kerajaan Malaysia telah menerima dan menyatakan komitmen untuk bersama-sama berusaha menjayakan SDG menjelang tahun 2030. Kementerian Pendidikan Malaysia (KPM) juga turut mempromosikan ESD dalam sistem pendidikan formal di Malaysia termasuk pendidikan sekolah menengah. Bagaimanapun, matlamat sebenar ESD diterapkan dalam pendidikan sekolah menengah di Malaysia masih belum dapat dipastikan lagi. Oleh itu, kajian ini bertujuan untuk meneliti matlamat ESD diterapkan dalam pendidikan geografi sekolah KSSM daripada perspektif guru-guru geografi di Malaysia. Pengkaji menggunakan tiga matlamat atau fungsi pendidikan yang dicadangkan oleh Gert Biesta iaitu kelayakan (qualification), sosialisasi dan subjektifikasi sebagai kerangka teoretikal yang akan menjadi panduan kepada pelaksanaan kajian ini. Kajian ini dijalankan menggunakan reka bentuk kajian kualitatif. Pengkaji menggunakan kaedah temu bual separa berstruktur bagi memperoleh data kajian. Sampel kajian terdiri daripada 11 orang guru geografi yang dipilih menggunakan kaedah persampelan bertujuan daripada 11 buah sekolah menengah di Malaysia. Data kajian dianalisis menggunakan kaedah analisis tematik yang dilakukan secara manual. Dapatan kajian menunjukkan matlamat guru menerapkan konsep ESD dalam mata pelajaran geografi KSSM di Malaysia lebih dominan kepada matlamat kelayakan dan sosialisasi. Manakala matlamat penerapan ESD untuk subjektifikasi masih belum begitu menonjol dalam landskap pendidikan geografi di Malaysia.
\end{abstract}

Kata kunci: pendidikan untuk pembangunan lestari, kelayakan, sosialisasi, subjektifikasi

\section{Education for Sustainable Development (ESD) purposes from the KSSM Geography teachers' perspectives}

\begin{abstract}
Education for Sustainable Development (ESD) is a global educational concept that serves to enhance the capabilities and competencies of the younger generation as global citizens to achieve the Sustainable Development Goals (SDGs). The Government of Malaysia has accepted and expressed its commitment to work together to ensure the success of the SDGs by 2030. The Ministry of Education (MOE) also promotes ESD integration in the formal education system in Malaysia including the secondary school education. However, the purposes of ESD to be integrated in secondary school education in Malaysia is yet to be ascertained. Therefore, this study aims to examine the purposes of ESD inculcated in the geography education of KSSM schools from the perspective of geography
\end{abstract}


teachers in Malaysia. Researchers used the three educational purposes or functions proposed by Gert Biesta namely qualification, socialization and subjectification as theoretical framework that will guide the implementation of this study. This study was conducted by using the qualitative research design. Semi-structured interview was used as the methods of data collection. The study samples consisted of 11 geography teachers from 11 secondary schools in Malaysia that was selected by using the purposive sampling. The findings were analyzed by using the thematic analysis which is done manually by the researchers. The findings show that the Malaysian geography teachers' purposes of incorporating ESD concept in their teaching for the qualification and socialization purposes are more prominent in this study. The purpose of subjectification has not become the major concern in the geography education landscape in Malaysia

Keywords: education for sustainable development, qualification, socialization, subjectification

\section{Pengenalan}

Pendidikan untuk Pembangunan Lestari (ESD) merupakan sebahagian daripada Matlamat Pembangunan Lestari (SDG) dalam Agenda 2030 yang telah dilancarkan oleh PBB dalam Persidangan PBB di New York pada tahun 2015 . SDG merupakan satu agenda global yang bermatlamat untuk melindungi bumi dari kemusnahan baharu dan memastikan kesejahteraan serta kemakmuran sejagat akan berjaya dicapai menjelang tahun 2030 (Bürgener \& Barth, 2017; Ofei-Manu \& Didham, 2018). Hasrat ini memerlukan komitmen, tindakan dan perubahan yang dilakukan secara kolektif dan berterusan seluruh warganegara global bagi membolehkan isu-isu kelestarian global mampu ditangani dengan lebih cepat dan menyeluruh (Cottafava et al., 2019).

Dalam usaha menangani isu-isu kelestarian global ini, pendidikan dilihat mempunyai peranan yang amat penting sebagai alat transformasi sosial. Peranan pendidikan dalam menangani isu-isu kelestarian global ini dinyatakan dengan jelas dalam SDG 4 Agenda 2030 yang menyatakan bahawa pendidikan berkualiti perlu disediakan kepada semua golongan bagi memperkasakan keupayaan masyarakat menghadapi cabaran globalisasi dan membina masa depan dunia yang lebih lestari pada masa hadapan(Cottafava et al., 2019; Singer-Brodowski et al., 2019). Untuk merealisasikan hasrat tersebut, PBB telah menetapkan ESD dan juga Pendidikan Kewarganegaraan Global (GCEd) sebagai jenis pendidikan yang paling bertepatan diterapkan dalam kesemua peringkat pendidikan formal, informal dan non-formal di semua negara melibatkan pembelajaran yang berlaku secara berterusan (O'Flaherty \& Liddy, 2018).

Apabila pendidikan secara umumnya dan ESD secara khususnya dikaitkan sebagai medium menangani isu-isu kelestarian global yang berlaku, maka timbul persoalan apakah sebenarnya matlamat ESD itu hendak diterapkan? Persoalan ini mendedahkan kita kepada kekompleksan hubungan antara pengetahuan, pertimbangan etika dan juga hasrat politik di sesebuah negara. Maka timbul pula persoalan baharu bagaimana pendidikan perlu memberikan respons apabila berlaku pertembungan antara nilai etika dan hasrat politik. Adakah ESD perlu memainkan peranan untuk menyatukan dan meredakan ketegangan yang berlaku dalam pertembungan antara nilai etika dan matlamat politik? Maka kita perlu jelas untuk apa sebenarnya kita mengambil keputusan untuk menerapkan ESD dalam sistem pendidikan kita? Persoalan ini wajar menjadi pertimbangan utama apabila kita menyatakan komitmen hendak menerapkan konsep ESD dalam sistem pendidikan formal kita di peringkat sekolah dan juga pengajian tinggi (Julien et al., 2018; Meadows, 2020; Yli-Panula et al., 2020).

Ini kerana setiap matlamat pendidikan yang ditetapkan akan mencorakkan bagaimana pendidikan tersebut akan diberikan kepada pelajar. Manakala pendidikan yang diberikan pula akan menentukan warganegara yang bagaimana yang akan dilahirkan daripada sistem pendidikan tersebut (Hasslöf et al., 2016). Kajian-kajian lepas berkaitan ESD dan dokumen-dokumen persidangan politik, ekonomi serta pendidikan yang diterbitkan di peringkat antarabangsa sering memberi penekanan terhadap keharmonian yang perlu dicapai melibatkan konflik di antara dimensi sosial dan ekonomi dengan alam 
sekitar ke arah mencapai pembangunan lestari. Kemahiran membuat keputusan yang terbaik apabila berdepan dengan konflik pembangunan lestari memerlukan masyarakat mempunyai keupayaan untuk berfikir secara kritikal (Hasslöf et al., 2014; Hasslöf \& Malmberg, 2015).

Oleh itu, kajian ini dijalankan bertujuan untuk melihat apakah matlamat penerapan konsep ESD dalam pendidikan geografi KSSM di Malaysia daripada perspektif guru-guru Geografi.

\section{Kerangka Teoretikal}

Matlamat pendidikan yang dominan dalam kebanyakan sistem pendidikan berkisar tentang meningkatkan kelayakan (qualification) pelajar. Matlamat qualification dikaitkan dengan proses sosial yang melayakkan pelajar melakukan sesuatu atau menjadi seseorang individu dengan peranan tertentu pada masa hadapan. melalui ilmu pengetahuan, nilai ataupun kemahiran tertentu yang diperoleh daripada pendidikan yang diberikan (Biesta, 2009; Nguyen, 2019). Matlamat qualification kebiasaannya mempunyai hubungan yang amat erat dengan pembangunan ekonomi di mana sistem pendidikan memainkan peranan untuk menyediakan pelajar menjadi tenaga kerja yang mahir. Pendidikan yang mampu melahirkan tenaga kerja yang mahir akan mampu menyumbang kepada peningkatan ekonomi sesebuah negara. Dalam konteks ESD, matlamat qualification adalah untuk membekalkan fakta dan pengetahuan yang dapat menangani isu kelestarian yang berlaku. Matlamat pendidikan ini dalam konteks ESD terbentuk daripada aliran pemikiran antroposentrisme moden dan berada di bawah falsafah pendidikan esensialisme. Guru yang mempunyai aliran pemikiran antroposentrisme moden cenderung memisahkan alam semula jadi dengan faktor kemanusiaan. Manakala falsafah esensialisme mengangkat prinsip pemindahan pengetahuan dan kandungan pembelajaran perlu berlaku daripada guru kepada pelajar. Guru perlu memindahkan fakta dan ilmu yang tepat kerana isu kelestarian yang berlaku adalah disebabkan oleh kurangnya pengetahuan saintifik. Isu kelestarian pula hanya tertumpu kepada isu alam sekitar sahaja (Sund \& Gericke, 2021; Van Poeck, 2019).

Bagaimanapun membekalkan pengetahuan dan kemahiran semata-mata adalah tidak memadai kerana melalui pendidikan juga pelajar akan lahir sebagai sebahagian daripada ahli masyarakat yang mengamalkan budaya dan norma yang tertentu. Maka di sinilah muncul matlamat pendidikan yang kedua yang dikenali sebagai matlamat sosialisasi. Matlamat sosialisasi meletakkan fungsi pendidikan sebagai proses menyediakan pelajar untuk menjadi ahli masyarakat yang memenuhi tuntutan norma, budaya dan politik sesebuah negara (Biesta, 2009, 2015). Oleh itu, apabila matlamat pendidikan itu ditetapkan untuk tujuan sosialisasi, aktiviti pembelajaran akan turut menumpukan kepada pemindahan nilai dan norma yang dimahukan ada dalam diri pelajar apabila mereka menjadi ahli masyarakat seiring dengan pengetahuan dan kemahiran yang diberikan ketika proses pendidikan berlaku (Nguyen, 2019). Dalam konteks ESD, pelajar akan didedahkan dengan nilai dan norma yang guru rasakan penting dalam menangani isu kelestarian global yang berlaku berlandaskan budaya dan agenda politik di negara masing-masing yang kebiasaannya tersirat sebagai agenda tersembunyi di dalam kurikulum kebangsaan ketika penerapan konsep ESD berlaku. Walaupun dikritik sebagai bersifat mendoktrin pemikiran pelajar tentang ESD (Jickling \& Wals, 2012) tapi hakikatnya pendidikan itu sendiri sifatnya tidak sepenuhnya neutral (Biesta, 2015). Guru yang menetapkan matlamat sosialisasi dalam penerapan konsep ESD dikatakan mempunyai aliran pemikiran biosentrisme dan memegang falsafah pendidikan progresivisme. Mereka beranggapan bahawa pengetahuan saintifik yang tepat dilengkapi dengan pengetahuan tentang norma dan nilai akan mampu mengubah gaya hidup semasa kepada yang lebih baik dan memenuhi norma kelestarian (Sund \& Gericke, 2021).

Rentetan daripada kritikan terhadap matlamat sosialisasi yang dilihat cenderung mendoktrinkan pemikiran pelajar dengan nilai dan norma (Jickling \& Wals, 2012) yang telah ditetapkan, maka terbentuk pula matlamat pendidikan yang ketiga yang dikenali sebagai subjektifikasi . Subjektifikasi ialah matlamat untuk membentuk karakter pelajar menjadi subjek politik. Politik di sini membawa maksud sisi antagonis yang terbentuk dalam perhubungan manusia (Biesta, 2009). Matlamat pendidikan ini adalah bertentangan dengan matlamat sosialisasi kerana ia membenarkan pelajar menggunakan pendekatan autonomi dan emansipasi dalam pemikiran dan tindakan ketika menilai baik 
dan buruk sesuatu perkara . Oleh itu, pelajar mestilah dirangsang untuk berfikir secara kritikal untuk memainkan peranan sebagai subjek politik yang berkesan dalam masyarakat. Subjektifikasi mendedahkan keunikan individu dan membuka ruang untuk menonjolkan agensi selain memberi kebebasan kepada individu untuk mencabar norma dan status quo (Hasslöf \& Malmberg, 2015). Dalam konteks ESD, matlamat pendidikan subjektifikasi mula diberi perhatian dalam landskap pendidikan kelestarian di peringkat global apabila timbul pelbagai ketidakpastian tentang isu kelestarian yang berlaku dan muncul pelbagai pendirian tentang bagaimana cara yang terbaik untuk menanganinya. Perspektif ESD yang berasaskan konflik menawarkan keterbukaan terhadap kepelbagaian pandangan. Matlamat pendidikan ke arah subjektifikasi membentuk pemikiran guru ke arah falsafah pendidikan rekonstruktivisme. Penekanan diberikan kepada pembentukan masa depan dunia yang lestari melalui peranan sekolah yang lebih demokratik dalam penerapan ESD. Matlamat subjektifikasi ini akan menjadi faktor pengimbang kepada matlamat sosialisasi (Sund \& Gericke, 2021).

\section{Metod Kajian}

\section{Reka bentuk Kajian dan kaedah pengumpulan data}

Kajian-kajian lepas banyak menumpukan terhadap pengetahuan ESD guru dan pelajar serta hubungannya dengan tingkah laku kelestarian mereka (Mahat et al., 2017, 2018, 2019). Selain itu, terdapat juga kajian yang mendedahkan cabaran penerapan ESD dalam konteks sekolah di Malaysia (Letchumanan \& Che Rose, 2021). Kajian ini dijalankan bertujuan untuk memahami matlamat penerapan ESD dalam pengajaran dalam konteks pendidikan geografi sekolah menengah di Malaysia daripada perspektif guru-guru geografi. Ini kerana bagaimana guru menetapkan matlamat penerapan konsep ESD akan menggambarkan apakah tradisi pengajaran geografi yang dominan di Malaysia. Oleh itu, pengkaji telah menggunakan pendekatan kajian kualitatif untuk tujuan ini. Ini kerana kajian kualitatif mampu memberikan dapatan yang lebih mendalam dan terperinci tentang fenomena yang hendak dikaji (Merriam \& Tisdell, 2016).

Pengkaji menggunakan kaedah temu bual separa berstruktur bagi memperoleh data kajian berkaitan matlamat penerapan konsep ESD dalam pengajaran geografi. Pengkaji melaksanakan proses temu bual dengan berpandukan kepada protokol temu bual yang telah disediakan lebih awal. Temu bual mengambil masa antara 60 hingga 90 minit untuk setiap informan kajian. Temu bual ini dilaksanakan antara bulan Ogos hingga September 2021. Transkripsi temu bual telah ditulis semula secara verbatim.

\section{Sampel Kajian}

Pengkaji menggunakan kaedah persampelan bertujuan bagi membolehkan data yang diperlukan untuk menjawab persoalan kajian dapat diberikan oleh informan yang dipilih (Miles et al., 2014; Patton, 2015). Informan kajian terdiri daripada 11 orang guru geografi yang mengajar di 11 buah sekolah menengah di Malaysia. Kriteria pemilihan informan untuk ditemu bual ialah informan terdiri daripada guru opsyen geografi yang mengajar geografi KSSM.

\section{Kaedah Analisis Data}

Data temu bual dianalisis menggunakan kaedah analisis tematik yang dilakukan secara manual. Pengkaji menganalisis transkrip temu bual terhadap informan kajian dan mengenal pasti kod-kod awalan (Braun \& Clarke, 2013; Maguire \& Delahunt, 2017) yang muncul berkaitan dengan matlamat penerapan konsep ESD dalam pengajaran. Kemudian kod-kod awalan tersebut diubahsuai bagi membentuk tema yang lebih tepat menerangkan tentang matlamat pendidikan dalam konteks ESD. 


\section{Hasil Kajian}

\section{Matlamat ESD untuk kelayakan (qualification)}

Dalam kajian ini, pengkaji telah menemukan 3 subtema di bawah penetapan matlamat penerapan konsep ESD untuk tujuan kelayakan iaitu menyediakan pelajar untuk 1) keperluan industri; 2) Aplikasi pengetahuan geografi dan ESD dan 3) kelangsungan dan daya tahan kehidupan

Hasil temu bual mendapati antara matlamat guru menerapkan konsep ESD dalam pengajaran geografi adalah untuk melengkapkan pelajar dengan pengetahuan ESD supaya mereka lebih bersedia untuk mengisi keperluan kerjaya masa hadapan di dalam industri yang berkaitan dengan pengetahuan ESD.

“...Pelajar ni suatu masa nanti dia akan keluar masuk pasaran kerja dalam macammacam bidang. Ada antaranya tu mungkin akan bekerja dalam benda yang memerlukan dia ada pengetahuan geografi dan ESD ni. Contohnya macam kalau satu hari nanti dia nak jadi pegawai perancang bandar...of course la dia kena ada pengetahuan Geografi dan ESD tu. Kalau takde pengetahuan yang baik...ha itu yang nanti jadi sesuka hati je nak tarah bukit, gondol hutan tu..."(TBG1)

“...Bagi saya bila kita mengajar ni tak kiralah apa subjek sekalipun...tak semestiya geografi dan ESD saja. Subjek lain pun sama. Memang tujuan dia tu nak pastikan pelajar kita tu dapat memenuhi keperluan industri la pada masa depan. Jadi tugas kita tu yang penting kita kena pastikan kita dah bagi betul-betul ilmu pengetahuan dalam subjek kita tu dekat pelajar kita. Sebab kalau diorang ni tak menguasai pengetahuan dengan baik...macam mana dia nak jawab soalan peperiksaan dengan baik. Kalau periksa pun teruk, nak sambung belajar pun tak boleh jadi tak dapat lah nanti nak tempatkan diri dalam industri..."(TBG3)

Selain itu, penerapan konsep ESD diberikan dalam pengajaran geografi diberikan penekanan supaya pelajar dapat mengaplikasikan semula pengetahuan mereka dalam proses membuat keputusan pada masa hadapan. Apabila sudah berada di dalam industri pada masa hadapan, pelajar akan terlibat dengan proses membuat keputusan melibatkan alam sekitar. Jadi pengetahuan ESD yang diterima di sekolah akan menjadi asas penting yang akan memandu keputusan tersebut. Isu kelestarian yang berlaku hanya akan dapat ditangani dengan pengetahuan ESD yang baik. Isu kelestarian yang diberi penekanan oleh guru adalah berkaitan dengan isu alam sekitar seperti guna tanah dan penerokaan sumber.

“...Kalau pengetahuan ESD ni kita terapkan kan, nanti bila diorang ni dh jadi seseorang satu hari nanti, saya yakin dengan pengetahuan nilah diorang boleh buat keputusan, contoh kalau dia nk buat jalan raya... dia boleh fikir patut ke tak patut nak buat jalan kat situ dengan pengetahuan dia tentang bentuk muka bumi kat situ,saliran yang ada, hutan dan sebagainya, contoh kalau buat jalan raya kat sini nanti jadi tanah runtuh. Jadi dia ada pengetahuan tentang sifat dan struktur muka bumi..."(TBG4)

“...Pelajar ni dalam kita tak sedar dan jangka, ada yang mungkin akan jadi pemimpin negara. Pengetahuan ESD yang kita bagi sekarang ni yang akan bentuk pemikiran dia nanti. Jadi kalau pengetahuan yang kita bagi tu betul, itu yang dia guna balik nanti nak buat dasar-dasar negara. Nak buat keputusan pasal pembangunan pun misalnya mestilah dia kena ada pengetahuan ESD tu dulu baru keputusan yang dibuat tu baik..."(TBG 6)

Guru juga menjadikan aspek kelangsungan hidup dan daya tahan kehidupan manusia sebagai matlamat mengapa mereka mahu konsep ESD diterapkan dalam pengajaran geografi KSSM. Menurut guru, kurangnya pengetahuan ESD akan mendorong kepada tindakan-tindakan yang boleh mengancam kepada kelestarian ekosistem. Apabila ekosistem terjejas, kesannya akan turut dirasai oleh manusia di Kawasan yang terjejas. Kelangsungan hidup akan terjejas dan daya tahan menghadapi kesan tindakan yang dilakukan mungkin akan berkurangan. 
“...Untuk diorang teruskan kelangsungan hidup diorang sendirilah...boleh bertahan teruskan kehidupan yang selesa. Dengan pengetahuan geografi dan ESD tu baru dia boleh nampak saling kebergantungan hubungan antara kita dengan ekosistem. Contoh kalau sungai tercemar dengan sisa toksik, nanti kat rumah takdak air...sebab bekalan air ditutup untuk rawatan. Jadi kalau ekosistem terancam diorang sama akan dapat kesan..." (TBG7)

\section{Matlamat ESD untuk sosialisasi}

Bagi tema matlamat penerapan ESD untuk tujuan sosialisasi pula, pengkaji telah menemui 3 subtema yang berkaitan dengan tema ini iaitu 1) mengamalkan nilai-nilai kelestarian yang dipelajari; 2) mempengaruhi ahli keluarga dan komuniti untuk mengamalkan gaya hidup lestari.

Sebahagian guru geografi yang ditemu bual menyatakan kepentingan memberi penekanan kepada elemen nilai dan norma kelestarian bersama dengan pengetahuan ESD yang diterapkan dalam pengajaran geografi kerana mereka mahukan penerapan konsep ESD dalam pengajaran mampu melahirkan warganegara yang mampu mempunyai kesedaran kelestarian yang tinggi dan mampu mengaplikasi gaya hidup yang lestari dalam kehidupan seharian seperti keupayaan menguruskan sisa domestik dengan baik melalui amalan pengasingan sisa pepejal dan sisa cecair mengikut kategori di punca iaitu di rumah sendiri. Guru mahu pelajar mengubah sikap dan gaya hidup melalui nilai-nilai kelestarian yang diajar.

“...Saya harap bila saya terap konsep ESD ni dalam pengajaran saya budak-budak ni bila dia dah tahu konsep ESD tu dia boleh praktikkan dalam kehidupan dia. Itu yang penting sekali bagi saya. Contoh bila saya ajar pasal tajuk sisa domestik kan, masa ajar tu kita bagi tugasan kat dia suruh buat aktiviti kumpulan terangkan pasal jenis-jenis sisa dan kaedah pengasingan sisa di punca ikut kategori. Kemudian kita mintak dia buat projek macam mana nak asingkan sisa tu dekat sekolah. Waktu kat sekolah tu saya nampaklah mereka boleh buat. Jadi saya cuba mintak mereka praktikkan pulak dekat rumah masingmasing dengan harapan benda ni jadi budaya dalam kehidupan mereka ni. Tapi lepas tu mereka amalkan ke tak saya pun tak berapa pasti la sebab benda ni melibatkan penerimaan family pulak macam mana..."(TBG2)

Selain itu, terdapat juga guru yang mahu pelajar mereka mula mengamalkan gaya hidup lestari pada skala kecil dan sederhana tetapi berterusan contohnya macam amalkan penjimatan elektrik dan sumber air, lepas tu kurangkan bebaskan gas Chlorofluorocarbon daripada penyaman udara yang amat mudah untuk dilakukan tetapi sukar untuk dijadikan amalan.

“...Harap pelajar ni boleh ubah la sikap dan gaya hidup diorang kepada gaya hidup yang lebih lestari bila saya ajar konsep ESD ni. Saya biasanya tak mintak diorang ubah benda yang besar-besar sangat contohnya nak suruh diorang fikir jalan nak selesaikan masalah pemanasan global. Memang penting isu pemanasan global tu. Tapi untuk pelajar saya, saya lebih selesa dia ubah yang kecik-kecik dulu. Yang dekat dengan dia. Yang hari-hari berlaku dalam hidup dia contohnya kalau dalam kelas atau kat rumah tu tak panas sangat...tak perlu bukak aircond. Guna kipas. Sekolah saya kelas dia ada aircond. Jadi diorang dh faham dah kalau masa geografi aircond memang tak bukak. Selain tu, saya suruh diorang jimat air dan elektrik.Bila tak guna elektrik tu, tutup suis..."(TBG8)

Selain itu, terdapat juga guru yang mahu pelajar menyebarkan nilai dan norma kelestarian yang dipelajari ini kepada keluarga dan masyarakat. Guru ini berpendapat tidak cukup dengan pelajar sahaja yang mengubah sikap dan gaya hidup kepada gaya hidup yang lebih lestari. Pengetahuan ESD yang mereka perolehi daripada proses pembelajaran geografi di sekolah dan kesedaran terhadap pentingnya memastikan sikap dan gaya hidup diubah seiring dengan pengetahuan ESD yang dimiliki perlu disebarluaskan kepada rakan-rakan, ahli keluarga dan masyarakat. Guru mahu pelajar bertindak 
sebagai agen perubahan dalam masyarakat. Ini kerana perubahan secara kolektif ke arah gaya hidup lestari akan menunjukkan impak yang lebih ketara di peringkat makro.

“...Saya memang mahu pelajar saya ni tinggi kesedaran ESD dia supaya dia boleh amalkan dalam kehidupan dia dan bawa pengaruh kelestarian ni dalam masyarakat. Selalunya saya akan ajar dan terapkan nilai tu based on pengalaman saya sendiri. Macam saya, saya ni suka tanam bunga dengan sayur dekat rumah. Dia macam terapi la kan bila kita penat-penat dapat bercakap dengan tanaman kita tu. Jadi apa yang saya tau sisa-sisa makanan ni boleh suburkan tanah. Buat baja kompos. Jadi saya cuba kongsi benda tu dengan pelajar saya. Mereka nampak bersemangat buat kat rumah masingmasing sebab lepas tu ada yang whatsapp tanya step nak buat tu. Ada yang malas sikit nak buat baja kompos tu dia kumpul dan campak direct je pegi tanaman dia. Dia cakap menjadi jugak buat macam tu..." (TBG10)

\section{Matlamat ESD untuk subjektifikasi}

Kajian ini mendapati matlamat penerapan konsep ESD dalam pengajaran geografi untuk tujuan subjektifikasi tidak begitu dominan dalam kalangan guru-guru geografi yang telah ditemu bual. Guru menyatakan kesediaan untuk menerima pandangan pelajar tetapi dengan had dan batasan yang ditetapkan guru. Guru bertindak mengawal sesi perkongsian pandangan supaya pelajar tidak tersasar daripada norma yang sepatutnya. Tambahan pula guru merasakan pemikiran pelajar masih belum cukup matang untuk melontarkan saranan dan pandangan yang bernas.

“...Saya memang terbuka nak terima pandangan pelajar. Tapi kita kena kawal la ...yela pelajar ni kadang-kadang dia belum matang sangat...tak semua pandangan dia kita boleh terima.." (TBG2)

Selain itu, guru juga tidak menggalakkan pelajar untuk menjadi terlalu kritikal dan vokal dalam melontarkan pandangan. Guru tidak mempunyai keyakinan untuk menyediakan ruang kepada perbincangan yang menyentuh isu-isu sensitif kerana bimbang akan kesan dan tindakan susulan yang mungkin diambil terhadap guru.

“...Kalau perkara-perkara yang sensitif tu kita tak benarkan la dia terbuka sangat luahkan pendapat. Lebih-lebih lagi kalau yang melibatkan politik atau pihak sekolah.Nanti jadi lain pulak. Kita pulak yang susah nanti. Biasanya cukup setakat saya jela..."(TBG4)

Guru berpendapat pelajar perlu menggunakan saluran yang tepat ketika hendak melontarkan kritikan atau pandangan. Pelajar tidak boleh diberi kebebasan bersuara tanpa bimbingan kerana guru khuatir pelajar menonjolkan imej buruk pula kepada masyarakat terhadap sekolah dan guru.

“...Boleh nak mengkritik tapi kena ikut saluran yang betul la. Tak boleh sesuka hati nak kritik macam tu. Nanti akan beri imej buruk pulak...”(TBG5)

Guru berpendapat pelajar perlu menggunakan pemikiran yang kritikal ketika menjawab soalan peperiksaan ataupun menjawab soalan tugasan yang diberi. Kemahiran pelajar berfikir secara kritikal yang dinyatakan guru lebih berkisarkan tentang peperiksaan dan tugasan sekolah. Guru menyatakan pelajar tidak mampu menulis skrip jawapan yang kritikal di mana pelajar tidak mampu menghuraikan dan memberi contoh terhadap fakta yang dinyatakan bagi menjawab soalan yang diberikan guru. Guru turut menyentuh tentang aspek kualiti jawapan pelajar yang rendah.

“...Kita mahu pelajar kita ni kritikal dalam memberi jawapan. Tapi masalahnya bila dia tulis jawapan tu, dia tak boleh menghurai dan beri contoh. Isi dengan fakta tu ada tapi tulah huraian dengan contoh tu diorang tak mampu bagi. Tak berkualiti jawapan tu..." (TBG7) 
“...Tak boleh nak lepas dia buat keputusan untuk pembelajaran sepenuhnya. Mereka ni kurang sifat berdikari. Cikgu memang tetap kena guide. Kalau tak tak jadi apa sampai ke sudah...pelajar saya belum sampai tahap tu lagi..."(TBG8)

\section{Matlamat ESD Jangka Pendek}

Selain daripada matlamat pendidikan jangka panjang untuk penerapan ESD dalam pengajaran geografi seperti kelayakan, sosialisasi dan subjektifikasi, guru-guru geografi di Malaysia turut meletakkan matlamat pendidikan jangka pendek ketika menerapkan ESD dalam pengajaran. Hasil temu bual yang dijalankan telah menemukan 2 tema yang menerangkan tentang matlamat ESD jangka pendek iaitu 1) prestasi peperiksaan pelajar dan 2) sasaran menghabiskan silibus mengikut rancangan pengajaran tahunan. Hasil temu bual bersama guru mendapati 3 orang guru yang ditemu bual hanya menetapkan matlamat penerapan ESD dalam pengajaran untuk jangka pendek sahaja.

Guru menekankan bahawa matlamat utama pendidikan yang diberikan kepada pelajar melalui pengajaran geografi dan ESD adalah supaya pelajar mereka mampu menunjukkan prestasi yang cemerlang dalam peperiksaan. Ini kerana guru menerima tekanan daripada pentadbir sekolah yang mahukan prestasi pelajar dalam peperiksaan sentiasa cemerlang. Matlamat guru untuk mencapai Gred Purata Mata Pelajaran (GPMP) yang tinggi bagi mata pelajaran geografi dalam peperiksaan SPM turut dinyatakan. Ini kerana guru tidak mahu mata pelajaran geografi menjadi penyebab kepada kejatuhan Gred Purata Sekolah (GPS) secara keseluruhan.

“...Yang penting kita nak mereka perform jawab soalan peperiksaan tu. Sebab kalau dia tak boleh jawab, prestasi teruk, penatdbir tanya kita balik apa yang kita buat masa mengajar dan apa yang kita ajar. Itu yang kita tak nak tu...(TBG5)

“...Kepuasan saya tu bila budak-budak ni dapat A dalam SPM supaya GPMP meningkat. Sebab subjek kita ni menyumbang juga dalam GPS sekolah. Kalau ramai gagal tu nanti subjek kita yang buat spoil kat GPS sekolah..."(TBG9)

Dapatan temu bual juga mendapati matlamat guru menerapkan konsep ESD dalam mata pelajaran geografi adalah untuk memastikan tuntutan silibus dipenuhi. Ini kerana pelajar perlu menduduki peperiksaan dalaman di sekolah walaupun peperiksaan PT3 dimansuhkan pada tahun ini. Tambahan pula, laporan Penilaian Bilik Darjah (PBD) bagi setiap individu pelajar tidak dapat disempurnakan jika guru gagal menghabiskan silibus. Perkara ini akan menjejaskan penilaian yang dilakukan pentadbir terhadap guru melalui Penilaian Bersepadu Pegawai Perkhidmatan Pendidikan (PBPPP).

“...Saya cuma fikir nak habiskan silibus je. Sebab mereka ni nanti nak jawab soalan peperiksaan tak bolehla kalau silibus tak habis. Walaupun PT3 takde tahun ni tapi peperiksaan dalaman tetap ada. Sekolah buat peperiksaan. Laporan PBD pun kena dilengkapkan juga. Lagipun kalau silibus tak habis efek jugak kita punya PBPPP..."(TBG11)

\section{Kesimpulan}

Kajian ini mendapati matlamat penerapan konsep ESD dalam pengajaran geografi KSSM boleh ditetapkan untuk jangka panjang (kelayakan (qualification), sosialisasi dan subjektifikasi) dan juga jangka pendek (peperiksaan dan tuntutan silibus). Secara keseluruhannya daripada 11 guru geografi yang ditemu bual 8 orang guru mempunyai matlamat penerapan konsep ESD jangka panjang manakala 3 orang guru selebihnya hanya menetapkan matlamat penerapan konsep ESD jangka pendek. 5 orang guru menjelaskan secara eksplisit mahupun implisit bahawa matlamat mereka menerapkan konsep ESD dalam pengajaran geografi adalah untuk tujuan kelayakan (qualification). 3 orang guru yang lain pula menetapkan matlamat penerapan konsep ESD dalam pengajaran Geografi untuk tujuan sosialisasi. Manakala 3 orang guru yang ditemu bual hanya menetapkan matlamat pengajaran jangka pendek sahaja. 
Daripada 3 matlamat jangka panjang yang telah dihuraikan pada bahagian kerangka teoretikal, kajian ini mendapati dalam penerapan ESD dalam konteks pengajaran geografi di Malaysia adalah lebih bermatlamatkan untuk tujuan kelayakan (qualification) dan sosialisasi. Untuk matlamat kelayakan, guru geografi menyatakan kepentingan pelajar menguasai pengetahuan ESD dan geografi untuk mendapatkan peluang yang lebih baik menempatkan diri dalam pasaran kerjaya. Selain itu, pelajar akan berpeluang mengaplikasikan pengetahuan ESD yang diperoleh untuk membantu proses membuat keputusan yang baik berkaitan pembangunan negara. Pengetahuan ESD yang baik juga akan membolehkan pelajar menentukan tindakan yang boleh menjamin kelangsungan hidup dan meningkatkan daya tahan menunjukkan guru berpegang kepada falsafah pendidikan esensialisme.

Bagaimanapun matlamat penerapan konsep ESD dalam pengajaran geografi tidak boleh dihadkan kepada penguasaan pengetahuan semata-mata tetapi perlu dilengkapi dengan nilai dan norma kelestarian yang cukup. Ini kerana pengetahuan ESD semata-mata tidak menjamin seseorang itu mempunyai kesedaran kelestarian yang tinggi dan mengamalkan gaya hidup yang lestari. Oleh itu, guru perlu menyalurkan nilai dan norma yang diperlukan bersama-sama dengan pengetahuan tentang konsep ESD yang diajar. Walaupun pengetahuan ESD mampu menjadi asas kepada keputusan yang baik dalam aspek kelestarian, tetapi nilai dan norma yang kuat akan menjadi agen perubahan sosial yang baik. Pelajar perlu terlibat aktif dalam proses pembelajaran dan pembelajaran berasaskan pengalaman akan lebih berkesan dalam mencapai matlamat pendidikan sosialisasi. Apabila corak pembelajaran seperti ini berlaku menunjukkan guru mengamalkan falsafah pendidikan progressivisme secara sedar mahupun tak sedar.

Di Malaysia, matlamat penerapan ESD untuk tujuan subjektifikasi masih belum diterima secara meluas lagi. Kajian ini mendapati guru-guru geografi mempunyai keraguan untuk menetapkan subjektifikasi sebagai matlamat konsep ESD diterapkan dalam pengajaran Geografi. Ini mungkin disebabkan oleh impak kolonialisme yang panjang di Malaysia iaitu selama 446 tahun mencorakkan sistem pendidikan Malaysia yang lebih menggalakkan pelajar berfikir dan bertindak dalam lingkungan norma yang perlu patuh dan mengikuti landasan pemikiran yang ditetapkan. Tambahan pula, guruguru sendiri juga berasal daripada sistem pendidikan yang sama. Selain itu, Malaysia juga mengamalkan nilai dan budaya ketimuran yang lebih bersopan-santun. Faktor ini mungkin menyebabkan mengapa matlamat subjektifikasi tidak begitu dominan di Malaysia walaupun ianya dilihat amat meluas dalam sistem pendidikan barat.

Kesimpulannya, Kementerian Pendidikan Malaysia (KPM) perlu menelusuri matlamat atau tujuan pendidikan yang dicadangkan oleh Biesta ini bagi membuat penetapan tentang hala tuju Pendidikan untuk Pembangunan Lestari (ESD) dalam sistem pendidikan formal khususnya pendidikan sekolah menengah di Malaysia. Matlamat pendidikan yang jelas berkaitan ESD perlu terpancar dalam kurikulum kebangsaan supaya guru-guru boleh menentukan tradisi pengajaran yang bersesuaian dengan matlamat pendidikan yang ditetapkan.

\section{Rujukan}

Biesta, G. (2009). Good education in an age of measurement: On the need to reconnect with the question of purpose in education. Educational Assessment, Evaluation and Accountability, 21, 33-46. https://doi.org/10.1007/s11092-008-9064-9

Biesta, G. (2015). What is education for? On good education, teacher judgement, and educational professionalism. European Journal of Education, 50(1), 75-87. https://doi.org/10.1111/ejed.12109

Braun, V., \& Clarke, V. (2013). Successful Qualitative Research: Practical Guide for Beginners (1st edit). SAGE Publications Ltd.

Bürgener, L., \& Barth, M. (2017). Sustainability competencies in teacher education: making teacher education count in everyday school practice. Journal of Cleaner Production, 1-14. https://doi.org/10.1016/j.jclepro.2017.10.263

Cottafava, D., Cavaglià, G., \& Corazza, L. (2019). Education of Sustainable Development Goals 
through students' active engagement: A transformative learning experience. Sustainability Accounting, Management and Policy Journal, 10(3), 521-544. https://doi.org/10.1108/SAMPJ05-2018-0152

Hasslöf, H., Ekborg, M., \& Malmberg, C. (2014). Discussing sustainable development among teachers: An analysis from a conflict perspective. International Journal of Environmental and Science Education, 9, 41-57. https://doi.org/10.12973/ijese.2014.202a

Hasslöf, H., Lundegård, I., \& Malmberg, C. (2016). Students' qualification in environmental and sustainability education - epistemic gaps or composites of critical thinking? International Journal of Science Education, 1-18. https://doi.org/10.1080/09500693.2016.1139756

Hasslöf, H., \& Malmberg, C. (2015). Critical thinking as room for subjectification in Education for Sustainable Development. Environmental Education Research, 21(2), 239-255. https://doi.org/10.1080/13504622.2014.940854

Jickling, B., \& Wals, A. E. J. (2012). Debating Education for Sustainable Development 20 Years after Rio: A conversation between Bob Jickling and Arjen Wals. Journal of Education for Sustainable Development, 6(1), 49-57. https://doi.org/10.1177/097340821100600111

Julien, M. P., Chalmeau, R., Vergnolle Mainar, C., \& Léna, J. Y. (2018). An innovative framework for encouraging future thinking in ESD: A case study in a French school. Futures, 101, 1-18. https://doi.org/10.1016/j.futures.2018.04.012

Letchumanan, K., \& Che Rose, R. A. (2021). Cabaran dan isu yang dihadapi dalam pelaksanaan Program Sekolah Lestari di Malaysia. Malaysian Journal of Society and Space, 17(1), 238-254.

Maguire, M., \& Delahunt, B. (2017). Doing a thematic analysis: a practical, step-by-step guide for learning and teaching scholars. AISHE-J: All Ireland Journal of Teaching and Learning in Higher Education, 3, 3351-33514.

Mahat, H., Hashim, M., Nayan, N., Norkhaidi, S. B., \& Saleh, Y. (2019). Development Of environmental awareness measurement instruments through Education for Sustainable Development. 8th UPI-UPSI International Conference (UPI-UPSI 2018), 239, 73-86. https://doi.org/10.2991/upiupsi-18.2019.13

Mahat, H., Hashim, M., Saleh, Y., Nayan, N., \& Norkhaidi, S. B. (2017). Pengetahuan dan amalan hijau dalam kalangan murid sekolah rendah. Jurnal Pendidikan Malaysia (Malaysian Journal of Education), 42(1), 41-49.

Mahat, H., Hashim, M., Saleh, Y., Nayan, N., \& Norkhaidi, S. B. (2018). Program komuniti sekolah karbon rendah melalui aktiviti Pendidikan Pembangunan Lestari. Journal of Human Capital Development, 11(1), 36-49.

Meadows, M. E. (2020). Geography Education for Sustainable Development. Geography and Sustainability, 1, 88-92. https://doi.org/10.1016/j.geosus.2020.02.001

Merriam, S. B., \& Tisdell, E. J. (2016). Qualitative Research : A Guide to Design and Implementation (4th ed., Vol. 148).

Miles, M. B., Huberman, A. M., \& Saldaña, J. (2014). Qualitative Data Analysis: A Methods Sourcebook (3rd ed.). SAGE Publications, Inc.

Nguyen, T. P. (2019). Searching for Education for Sustainable Development in Vietnam. Environmental Education Research, 25(7), 1-14. https://doi.org/10.1080/13504622.2019.1569202

O'Flaherty, J., \& Liddy, M. (2018). The impact of Development Education and Education for Sustainable Development interventions: a synthesis of the research. Environmental Education Research, 24(7), 1031-1049. https://doi.org/10.1080/13504622.2017.1392484

Ofei-Manu, P., \& Didham, R. J. (2018). Identifying the factors for sustainability learning performance. Journal of Cleaner Production, 1-24. https://doi.org/10.1016/j.jclepro.2018.06.126

Patton, M. Q. (2015). Qualitative Research and Evaluation Methods : Integrating Theory and Practice (4th ed.). SAGE Publications, Inc.

Singer-Brodowski, M., Etzkorn, N., \& von Seggern, J. (2019). One transformation path does not fit all-insights into the diffusion processes of Education for Sustainable Development in different educational areas in Germany. Sustainability (Switzerland), 11(269), 1-17. https://doi.org/10.3390/su11010269

Sund, P. J., \& Gericke, N. (2021). More than two decades of research on selective traditions in environmental and sustainability education-seven functions of the concept. Sustainability (Switzerland), 13(6524), 1-14. https://doi.org/10.3390/su13126524 
Malaysian Journal of Social Sciences and Humanities (MJSSH), Volume 6, Issue 10, (page 54 - 64), 2021

$$
\text { DOI: https://doi.org/10.47405/mjssh.v6i10.1110 }
$$

Van Poeck, K. (2019). Environmental sustainability education in a post-truth era. An exploration of epistemology and didactics beyond the objectivism-relativism dualism. Environmental Education Research, 25(4), 472-491.

Yli-Panula, E., Jeronen, E., \& Lemmetty, P. (2020). Teaching and learning methods in geography promoting sustainability. Education Sciences, 10(1). 